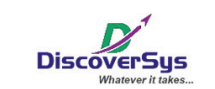

Published by DiscoverSys

\section{Factors related to parent's participation in child dental health care in Tegallalang I Public Health Centre}

Vivin Sumanti, ${ }^{1,4^{*}}$ I Ketut Tangking Widarsa, ${ }^{1,3}$ Dyah Pradnyaparamita Duarsa, ${ }^{1,2}$

\section{ABSTRACT}

The public health centre reports showed that the level of parent's participation in children dental health care in Tegallalang I Public Health Centre was low (31.7\%-35.1\%). This study aims to determine the relationship between parent's knowledge, attitudes, motivation and transportation accessibility to parent's participation in child dental health care in Tegallalang I Public Health Centre. A cross-sectional study was conducted to 100 parents whose children were referred to undergo dental health examinations in Tegallalang I Public Health Centre using a systematic random sampling method. Data of knowledge, attitudes, motivation and transportation accessibility were collected using an interview guide, while parent's participation was obtained from dental care registration. The data were analised by logistic regression. The results showed that level of parent's participation in child dental health care was low (41\%). Variables that were significantly associated with level of parent's participation in child dental health care were knowledge $[O R=7.35 ; p=0.001]$, motivation $[O R=4.89$; $p=0.028]$ and attitudes $[O R=4.19 ; p=0.039$ ). Transport accessibility was not associated with parent's participation $[0 R=2.35 ; p=0.123]$. The conclusion of this study is that parent's participation in child dental health care was influenced by parent's knowledge about oral health, motivation and attitudes towards child dental health care. It is recommended to upscale health promotion related to dental health and the benefits of treatment in order to encourage parent's participation in children dental health care.

Keywords: knowledge, attitude, motivation, parent's participation, child dental health care Cite This Article: Sumanti, V., Widarsa, I.K.T., Duarsa, D.P. 2013. Factors related to parent's participation in child dental health care in Tegallalang I Public Health Centre. Public Health and Preventive Medicine Archive 1(1): 35-39. D0I:10.15562/phpma.v1i1.156

\title{
Faktor yang berhubungan dengan partisipasi orang tua dalam perawatan kesehatan gigi anak di Puskesmas Tegallalang I
}

\section{ABSTRAK}

Laporan Puskesmas Tegallalang I menunjukkan bahwa tingkat partisipasi orang tua dalam perawatan kesehatan gigi dan mulut anak di wilayah kerja puskesmas masih kurang (31,7\%-35,1\%). Penelitian ini bertujuan untuk mengetahui hubungan antara pengetahuan, sikap, motivasi orang tua dan ketersediaan alat transportasi dengan tingkat partisipasi orang tua dalam perawatan kesehatan gigi dan mulut anak di Puskesmas Tegallalang I. Penelitian dilakukan secara cross-sectional pada 100 orang tua yang anaknya dirujuk untuk melakukan perawatan kesehatan gigi dan mulut di Puskesmas Tegallalang I yang dipilih secara random. Data pengetahuan, sikap, motivasi dan ketersediaan alat transportasi dikumpulkan menggunakan pedoman wawancara, sedangkan partisipasi orang tua didapat dari register pelayanan gigi. Data dianalisis dengan regresi logistik. Hasil penelitian menunjukkan bahwa tingkat partisipasi orang tua dalam perawatan kesehatan gigi dan mulut anak masih kurang (41\%). Variabel yang berhubungan secara signifikan dengan tingkat partisipasi orang tua dalam perawatan kesehatan gigi dan mulut anak adalah pengetahuan $[0 R=7,35 ; p=0,001]$, motivasi $[0 R=4,89 ; p=0,028]$, dan sikap $[0 R=4,19 ; p=0,039]$. Ketersediaan alat transportasi tidak terbukti berhubungan $[0 R=2,35$; $p=0,123]$. Berdasarkan hasil penelitian dapat disimpulkan bahwa partisipasi orang tua dalam perawatan kesehatan gigi dan mulut anak dipengaruhi oleh pengetahuan orang tua tentang kesehatan gigi dan mulut, sikap dan motivasi orang tua terhadap perawatan kesehatan gigi dan mulut anak. Diharapkan kepada puskesmas untuk meningkatkan penyuluhan tentang kesehatan gigi dan mulut serta manfaat perawatannya untuk meningkatkan partisipasi orang tua dalam perawatan kesehatan gigi dan mulut anak.
${ }^{*}$ Correspondence to: Vivin Sumanti, Public Health Postgraduate Program Udayana University, Tegallalang I Public Health Centre, Gianyar District vivin_sumanti@yahoo.com
Kata kunci: pengetahuan, sikap, motivasi, partisipasi orang tua, kesehatan gigi dan mulut anak

Kutip artikel ini: Sumanti, V., Widarsa, I.K.T., Duarsa, D.P. 2013. Faktor yang berhubungan dengan partisipasi orang tua dalam perawatan kesehatan gigi anak di Puskesmas Tegallalang I. Public Health and Preventive Medicine Archive 1(1): 35-39. D01:10.15562/phpma.v1i1.156 


\section{PENDAHULUAN}

Kesehatan gigi dan mulut merupakan komponen penting dari kesehatan, dimana penyakit gigi dan mulut masih banyak ditemukan di masyarakat. Sebaliknya masyarakat yang memanfaatkan pelayanan kesehatan gigi masih rendah $(29,6 \%)$, dari $23,4 \%$ penduduk yang mengalami gangguan kesehatan gigi. ${ }^{1}$ Hal yang sama ditemukan di Puskesmas Tegallalang I, dimana tingkat pemanfaatan pelayanan kesehatan gigi oleh anak usia sekolah tiga tahun terakhir di Puskesmas Tegallalang I berturut-turut 31,70\% (tahun 2010), $32,87 \%$ (tahun 2011) dan 35,10\% (tahun 2012). Ini berarti hanya sepertiga dari penduduk yang memerlukan perawatan kesehatan gigi mencari pengobatan ke tempat pelayanan kesehatan.

Rendahnya pemanfaatan pelayanan kesehatan gigi bagi anak usia sekolah disebabkan oleh faktor internal dan eksternal. Menurut konsep Pedodontic Treatment Triangle, pemanfaatan pelayanan kesehatan gigi anak ditentukan oleh interaksi dari tiga komponen yaitu anak sebagai penerima layanan, petugas kesehatan sebagai motivator dan penyedia layanan serta orang tua sebagai motivator dan pengambil keputusan dalam perawatan gigi anak. ${ }^{2}$ Ditinjau dari teori Lawrence Green, terbentuknya perilaku individu dipengaruhi oleh tiga faktor yaitu faktor predisposisi (predisposing factors) yang meliputi pengetahuan, sikap, tradisi, sistem nilai, tingkat pendidikan, sosial ekonomi; faktor pemungkin (enabling factors) meliputi ketersediaan sarana dan prasarana kesehatan, akses pelayanan, mutu pelayanan; dan faktor penguat (reinforcingfactors) meliputi sikap dan perilaku tokoh masyarakat, tokoh agama, petugas kesehatan dan peraturan perundang-undangan yang terkait dengan kesehatan. ${ }^{3}$

Dalam penelitian ini dianalisis hubungan faktor internal dan faktor eksternal yang dianggap relevan dengan tempat penelitian. Faktor internal yang diteliti adalah pengetahuan orang tua tentang karies gigi dan perawatannya, sikap serta motivasi orang tua dalam perawatan kesehatan gigi dan mulut anak. Sedangkan faktor eksternal yang diteliti adalah ketersediaan alat transportasi.

\section{METODE}

Penelitian ini dilakukan di wilayah kerja Puskesmas Tegallalang I di Kabupaten Gianyar, dari Bulan Januari-Pebruari 2013 dengan menggunakan rancangan cross-sectional analitik. Semua orang tua anak sekolah dasar yang berdomisili di wilayah kerja Puskesmas Tegallalang I, yang anaknya mendapatkan surat rujukan dari tim Usaha Kesehatan Gigi Sekolah (UKGS) untuk melakukan perawatan kesehatan gigi dan mulut di Puskesmas Tegallalang I, menjadi populasi penelitian yang berjumlah 396 orang. Dari populasi tersebut dipilih 100 orang secara systematic random sampling sebagai sampel. Jumlah sampel tersebut ditentukan berdasarkan asumsi proporsi yang tidak memanfaatkan pelayanan kesehatan sebesar $65 \%$, dengan tingkat kemaknaan 5\% dan deviasi (d) 10\%. ${ }^{4}$

Variabel yang diukur adalah partisipasi orang tua dalam perawatan kesehatan gigi dan mulut anak di Puskesmas Tegallalang I sebagai variabel terikat, sedangkan pengetahuan orang tua tentang karies gigi dan perawatannya, sikap dan motivasi orang tua terhadap perawatan kesehatan gigi dan mulut, serta ketersediaan alat transportasi sebagai variabel bebas. Pengumpulan data dilakukan oleh peneliti dengan wawancara di rumah responden yang sebelumnya telah diuji validitas dan reliabilitasnya. Pedoman wawancara untuk pengetahuan terdiri dari 15 pernyataan tentang karies gigi dan perawatannya yang meliputi aspek penyebab karies gigi dan perawatannya dengan pilihan jawaban benar (skor 1) atau salah (skor 0). Pedoman wawancara sikap terdiri dari 14 pernyataan tentang perawatan kesehatan gigi dan mulut yang meliputi aspek persepsi terhadap kerentanan penyakit, keseriusan penyakit, manfaat perawatan dan manfaat yang dirasakan bila melakukan perawatan dengan menggunakan Skala Likert (sangat setuju skor 4, setuju skor 3, tidak setuju skor 2 dan sangat tidak setuju skor 1. Pedoman wawancara motivasi terdiri dari 11 pernyataan tentang motivasi dalam perawatan kesehatan gigi dan mulut yang meliputi aspek pemenuhan kebutuhan dan harapan dengan menggunakan Skala Likert (sangat setuju skor 4, setuju skor 3, tidak setuju skor 2 dan sangat tidak setuju skor 1), dan 7 pernyataan tentang ketersediaan alat transportasi meliputi jenis ketersediaan alat transportasi dan fasilitas pendukungnya dengan pilihan jawaban ya (skor 1) atau tidak (skor 0). Sedangkan partisipasi diukur menggunakan data sekunder yang terdapat pada register pelayanan gigi di Puskesmas Tegallalang I. Pengetahuan, sikap, motivasi dan ketersediaan alat transportasi dikategorikan menjadi dua yaitu kategori baik $(\geq$ percentile 75$)$ dan kategori kurang baik $(<$ percentile $75)$. Sedangkan partisipasi dikategorikan menjadi berpartisipasi dan tidak berpartisipasi.

Karakteristik responden dianalisis secara univariat, sedangkan hubungan antara pengetahuan, sikap, motivasi dan ketersediaan alat transportasi terhadap partisipasi orang tua dalam perawatan kesehatan gigi dan mulut anak di Puskesmas Tegallalang I dianalisis secara bivariat dan multivariat. Analisis bivariat menggunakan uji chi square dan taraf uji nyata $(\alpha)=5 \%$, sedangkan analisis multivariat menggunakan regresi logistik dengan taraf uji nyata $(\alpha)=5 \%$. Penelitian ini mendapatkan 
kelaikan etik dari Komisi Etik Penelitian Fakultas Kedokteran Universitas Udayana/Rumah Sakit Umum Pusat Sanglah Denpasar.

\section{HASIL}

Semua sampel yang terpilih dapat berpartisipasi dalam penelitian ini dan tidak ada penolakan. Analisis terhadap karakteristik responden disajikan pada Tabel 1.

Tabel 1 Distribusi frekuensi karakteristik responden

\begin{tabular}{lc}
\hline Karakteristik & $\mathbf{f}(\mathbf{\%})$ \\
\hline Desa & $26(26,0)$ \\
Tegallalang & $23(23,0)$ \\
Kenderan & $27(27,0)$ \\
Kedisan & $24(24,0)$ \\
Keliki & \\
Jenis kelamin & $82(82,0)$ \\
Laki-laki & $18(18,0)$ \\
Perempuan & \\
Umur & $8(8,0)$ \\
25-34 tahun & $73(73,0)$ \\
35-44 tahun & $19(19,0)$ \\
$>44$ & \\
Pendidikan & $72(72,0)$ \\
Pendidikan dasar & $28(28,0)$ \\
SMA ke atas & \\
Pekerjaan & $18(18,0)$ \\
Formal & $82(82,0)$ \\
Non formal &
\end{tabular}

Tabel 1 menunjukkan bahwa responden tersebar secara merata di keempat desa yang didominasi oleh responden dengan jenis kelamin laki-laki. Responden sebagian besar berusia 35-34 tahun, dengan tingkat pendidikan dasar dan bekerja di sektor nonformal.

Analisis bivariat dan multivariat menunjukkan tiga variabel yang berperan terhadap partisipasi orang tua dalam perawatan kesehatan gigi dan mulut anak di Puskesmas Tegallalang I yaitu pengetahuan orang tua tentang karies gigi dan perawatannya, sikap dan motivasi orang tua terhadap perawatan kesehatan gigi dan mulut. Tabel 2 menunjukkan partisipasi dipengaruhi oleh pengetahuan orang tua tentang karies gigi dan perawatannya, sikap dan motivasi orang tua dalam perawatan kesehatan gigi dan mulut. Pengetahuan orang tua merupakan variabel yang berperan dominan mempengaruhi partisipasi orang tua dalam perawatan kesehatan gigi dan mulut anak di Puskesmas Tegallalang I.

Tabel 2 menunjukkan partisipasi dipengaruhi oleh pengetahuan orang tua tentang karies gigi dan perawatannya, sikap dan motivasi orang tua dalam perawatan kesehatan gigi dan mulut. Pengetahuan orang tua merupakan variabel yang berperan dominan mempengaruhi partisipasi orang tua dalam perawatan kesehatan gigi dan mulut anak di Puskesmas Tegallalang I.

\section{DISKUSI}

Hasil analisis menunjukkan bahwa tingkat partisipasi orang tua dalam perawatan kesehatan gigi dan mulut anak di Puskesmas Tegallalang I masih kurang yaitu sebesar $41 \%$. Kurangnya tingkat partisipasi orang tua dalam perawatan kesehatan

Tabel 2 Crude dan adjusted OR faktor-faktor yang berhubungan dengan partisipasi orang tua dalam perawatan kesehatan gigi dan mulut anak

\begin{tabular}{|c|c|c|c|c|c|c|}
\hline \multirow[b]{2}{*}{ Variabel } & \multicolumn{2}{|c|}{ Tingkat partisipasi orang tua } & \multicolumn{2}{|c|}{ Crude } & \multicolumn{2}{|c|}{ Adjusted } \\
\hline & Kurang & Baik & OR & $\mathbf{p}$ & OR & $\mathbf{p}$ \\
\hline \multicolumn{7}{|c|}{ Pengetahuan } \\
\hline Kurang & $45(76,30 \%)$ & $14(23,70 \%)$ & 6,19 & $<0,001$ & 7,35 & $<0,001$ \\
\hline Baik & $14(34,10 \%)$ & $27(65,90 \%)$ & & & & \\
\hline \multicolumn{7}{|l|}{ Sikap } \\
\hline Kurang & $49(68,10 \%)$ & $23(31,90 \%)$ & 3,84 & 0,006 & 4,19 & 0,039 \\
\hline Baik & $10(35,70 \%)$ & $18(64,30 \%)$ & & & & \\
\hline \multicolumn{7}{|l|}{ Motivasi } \\
\hline Kurang & $51(68,90 \%)$ & $23(31,10 \%)$ & 4,99 & 0,001 & 4,89 & 0,028 \\
\hline Baik & $8(30,80 \%)$ & $18(69,20 \%)$ & & & & \\
\hline \multicolumn{7}{|c|}{ Alat transportasi } \\
\hline Kurang & $45(63,40 \%)$ & $26(36,60 \%)$ & 1,85 & 0,184 & 2,35 & 0,123 \\
\hline Baik & $14(48,30 \%)$ & $15(51,70 \%)$ & & & & \\
\hline
\end{tabular}


gigi dan mulut anak di Puskesmas Tegallalang I disebabkan oleh kurangnya pengetahuan orang tua tentang karies gigi dan perawatannya, kurangnya sikap dan motivasi orang tua terhadap perawatan kesehatan gigi dan mulut. Sebaliknya pengetahuan yang cukup dan sikap yang baik tentang kesehatan gigi dan mulut diperlukan untuk menumbuhkan perilaku yang bersifat konsisten. ${ }^{5}$

Sikap yang negatif dan motivasi yang kurang dari orang tua tentang kesehatan gigi dan mulut dapat menghambat orang tua untuk berperilaku positif dalam hal ini tidak berpartisipasi dalam perawatan kesehatan gigi dan mulut. Padahal sikap dan motivasi dibutuhkan sebagai reinforcement atau stimulus yang akan membentuk perilaku individu. Motivasi juga dapat memperkuat dan mempertahankan tingkah laku yang dikehendaki. Sikap dan motivasi yang kurang timbul oleh karena informasi dan pengetahuan yang kurang, atau dipengaruhi pengalaman orang lain yang negatif terhadap perawatan kesehatan gigi dan mulut yang pernah didapat. ${ }^{6}$

Sejalan dengan teori Lawrence Green, bahwa perilaku akan dipengaruhi oleh faktor internal dan eksternal. ${ }^{3}$ Partisipasi dalam perawatan kesehatan gigi dan mulut sebagai cerminan perilaku kesehatan individu dipengaruhi sikap dan motivasi yang muncul karena tingkat pengetahuan yang baik. ${ }^{4}$ Sedangkan faktor eksternal seperti jarak ke tempat pelayanan belum tentu berhubungan dengan partisipasi. Hal ini didukung oleh penelitian sejenis yang menyimpulkan bahwa jarak bukan menjadi kendala dalam memanfaatkan pelayanan kesehatan jika transportasi mendukung.?

Pengetahuan yang kurang dapat disebabkan oleh tingkat pendidikan yang kurang, dimana sebagian besar $(66,6 \%)$ responden berpendidikan dasar dan bekerja disektor nonformal $(81,4 \%)$. Hal ini tentunya dapat mempengaruhi kemampuan orang tua untuk mengakses informasi dan pemahaman terhadap manfaat perawatan kesehatan gigi dan mulut bagi anak sehingga timbul motivasi dan sikap yang kurang baik terhadap perawatan kesehatan gigi dan mulut anak. Tingkat pendidikan sangat berpengaruh pada pemanfaatan pelayanan kesehatan gigi, ini berarti semakin tinggi tingkat pendidikan seseorang maka semakin tinggi pula tingkat pemanfaatan pelayanan kesehatan gigi. ${ }^{8,9}$

Penelitian lain yang dilakukan di Kelurahan Sari Rejo juga menyimpulkan bahwa tingkat pendidikan mempengaruhi pengetahuan seseorang, dimana sebagian besar respondennya berpendidikan dasar dan tidak tahu kapan waktu yang tepat untuk memeriksakan kesehatan giginya. ${ }^{10}$

Kurangnya pengetahuan dan pemahaman dari orang tua juga disebabkan karena kurangnya penyuluhan tentang kesehatan gigi dan mulut serta perawatannya oleh petugas kesehatan. Kurangnya penyuluhan tentang kesehatan gigi dan mulut serta perawatannya disebabkan oleh jam kerja petugas kesehatan tidak sesuai dengan waktu luang masyarakat, dimana sebagian besar orang tua bekerja di sektor nonformal sebagai pengerajin.

Penyuluhan kesehatan yang diberikan secara intensif dan berlangsung secara terus menerus, dengan menggunakan alat peraga dan ilustrasiilustrasi lebih tepat diterapkan pada masyarakat dengan tingkat pendidikan yang masih rendah, agar informasi yang disampaikan mudah dipahami. Selain itu penyuluhan difokuskan untuk meningkatkan pemahaman masyarakat tentang risiko dan manfaat perawatan kesehatan gigi dan mulut pada anak. Dengan demikian, masyarakat diharapkan lebih peduli dengan kesehatan gigi anak sehingga mau berpartisipasi lebih baik. Posyandu balita dan pertemuan bulanan ibu-ibu PKK yang berlangsung secara rutin dapat dimanfaatkan untuk menyampaikan penyuluhan tentang kesehatan gigi dan mulut. Memberdayakan kader posyandu dalam promosi kesehatan sebagai peer education lebih efektif dan mampu mempertahankan retensi pengetahuan dibandingkan dengan menggunakan metode ceramah. ${ }^{11}$

Iklan layanan masyarakat tentang kesehatan gigi dan mulut juga bisa disampaikan melalui media audio visual yang ditayangkan di ruang tunggu pasien dapat menjadi pertimbangan berikutnya untuk meningkatkan pengetahuan masyarakat tentang kesehatan gigi dan mulut. Penelitian juga menunjukkan bahwa ibu-ibu yang diberi penyuluhan dengan menggunakan audio visual memiliki pengetahuan yang lebih baik daripada ibu-ibu yang diberi penyuluhan dengan menggunakan modul. ${ }^{12,13}$ Pengetahuan dan sikap individu yang baik dapat memberikan pengaruh yang cukup besar terhadap pemeliharaan kesehatan gigi dan mulut. ${ }^{14}$

Salah satu kelemahan dalam penelitian ini adalah tidak terdeteksinya partisipasi orang tua yang mencarikan perawatan kesehatan gigi dan mulut anaknya diluar Puskesmas Tegallalang I karena tidak tercatat di register pelayanan, dan pada saat pengumpulan data tidak ditanyakan apakah anak yang membutuhkan perawatan kesehatan gigi dan mulut telah mendapat pelayanan di tempat lain seperti dokter gigi praktek swasta. Selain itu faktorfaktor yang mempengaruhi partisipasi yang diteliti terbatas pada faktor internal yaitu pengetahuan, sikap dan motivasi serta faktor eksternal yaitu ketersediaan alat transportasi. Sedangkan faktorfaktor lain yang berpengaruh terhadap partisipasi tidak diteliti oleh karena keterbatasan dan kemampuan peneliti. 


\section{SIMPULAN}

Dari penelitian ini dapat disimpulkan bahwa partisipasi orang tua dalam perawatan kesehatan gigi dan mulut anak yang memiliki masalah kesehatan gigi dan mulut masih rendah. Rendahnya partisipasi berkaitan dengan kurangnya pengetahuan orang tua tentang karies gigi dan perawatannya, kurangnya sikap orang tua terhadap upaya perawatan kesehatan gigi dan mulut serta kurangnya motivasi orang tua untuk memeriksakan gigi dan mulut anak. Kurangnya partisipasi ini berkaitan dengan tingkat pendidikan yang rendah dan pekerjaan responden yang sebagian bekerja di sektor nonformal serta kurangnya penyuluhan tentang kesehatan gigi dan mulut oleh petugas kesehatan.

Untuk meningkatkan partisipasi orang tua dalam perawatan kesehatan gigi dan mulut anak, perlu dilakukan upaya penyuluhan secara terus menerus dengan metode yang mempertimbangkan tingkat pendidikan masyarakat dan memanfaatkan kegiatan-kegiatan seperti posyandu balita dan pertemuan-pertemuan yang biasa dilakukan oleh masyarakat.

\section{UCAPAN TERIMA KASIH}

Ucapan terima kasih penulis sampaikan kepada Kepala Dinas Kesehatan Kabupaten Gianyar dan Kepala Puskesmas Tegallalang I yang telah memberikan ijin penelitian, tim UKGS, serta seluruh responden yang telah berpartisipasi secara langsung maupun tidak langsung.

\section{DAFTAR PUSTAKA}

1. Departemen Kesehatan RI. Laporan hasil Riset Kesehatan Dasar (RISKESDAS) Nasional. Jakarta: Badan Penelitian dan Pengembangan Kesehatan; 2008.
2. Chandra S. Textbook of community dentistry. $2^{\text {nd }}$ ed. Delhi: Lordson Publisher (P) Ltd; 2007.

3. Notoatmodjo S. Promosi kesehatan: Teori dan aplikasi. Jakarta: Rineka Cipta; 2005.

4. Lemeshow S. \& David WH Jr. Besar sampel dalam penelitian kesehatan (terjemahan). Yogyakarta: Gadjahmada University Press; 1997.

5. Kandera W. Pendidikan kesehatan masyarakat dan beberapa aspeknya. Denpasar: Universitas Udayana; 2004.

6. Djaali H. Psikologi pendidikan. Jakarta: PT Bumi Aksara; 2012.

7. Liestiani E. Pengaruh aksesibilitas terhadap wilayah pelayanan puskesmas di Kota Magelang berdasarkan persepsi pengunjung [skripsi]. Semarang: Fakultas Teknik Universitas Diponegoro; 2006.

8. Hendrartini J. Analisis pemanfaatan unit pelayanan kesehatan gigi di rumah sakit: kajian di RS Sardjito dan RS Bethesda [tesis]. Yogyakarta: MIKM UGM; 1995.

9. Laela DS. Determinan permintaan masyarakat terhadap pelayanan kesehatan gigi pada Klinik AKG Depkes Bandung [tesis]. Yogyakarta: IKG UGM; 2001.

10. Alamsyah RM. Need pemeriksaan dan perawatan gigi pada ibu-ibu di Kelurahan Sari Rejo Kecamatan Polonia Kotamadya Medan tahun 2009 [skripsi]. Medan: Universitas Sumatera Utara; 2010.

11. Murti ES, Prabandari YS, dan Riyanto BS. Efektifitas promosi kesehatan dengan peer education pada kelompok dasawisma dalam upaya penemuan tersangka penderita TB baru. Berita Kedokteran Masyarakat. September 2006: 22(3); 128-134.

12. Kapti RE. Efektifitas audiovisual sebagai media penyuluhan kesehatan terhadap peningkatan pengetahuan dan sikap ibu dalam tatalaksana balita dengan diare di dua rumah sakit Kota Malang [tesis]. Jakarta: Universitas Indonesia; 2010.

13. Rahmawati I, Sudargo T, dan Paramastri I. Pengaruh penyuluhan dengan media audiovisual terhadap peningkatan pengetahuan, sikap dan perilaku ibu balita gizi kurang dan buruk di Kabupaten Kota Waringin Barat Propinsi Kalimantan Tengah. Jurnal Gizi Klinik Indonesia. November 2007: 4(2); 69-77.

14. Tjahja I. dan Lely MA. Hubungan kebersihan gigi dan mulut dengan pengetahuan dan sikap responden di beberapa puskesmas di Propinsi Jawa Barat. Media Litbang Kesehatan. 2005: XV(4).

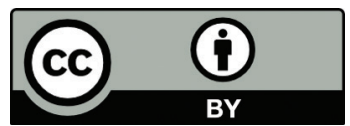

This work is licensed under a Creative Commons Attribution 